Article

\title{
Improving the Recovery of Phenolic Compounds from Spent Coffee Grounds (SCG) by Environmentally Friendly Extraction Techniques
}

\author{
Ilhami Okur $^{1,2} \mathbb{D}^{\mathbb{D}}$, Betul Soyler ${ }^{1} \mathbb{D}$, Purlen Sezer $^{1}\left(\mathbb{D}\right.$, Mecit Halil Oztop $^{1}$ and Hami Alpas ${ }^{1, *(\mathbb{D})}$ \\ 1 Department of Food Engineering, Middle East Technical University, 06800 Ankara, Turkey; \\ ilhami.okur@metu.edu.tr (I.O.); betulsoyler06@gmail.com (B.S.); purlen.sezer@metu.edu.tr (P.S.); \\ mecit@metu.edu.tr (M.H.O.) \\ 2 Department of Food Engineering, Niğde Ömer Halisdemir University, 51240 Niğde, Turkey \\ * Correspondence: imah@metu.edu.tr
}

Citation: Okur, I.; Soyler, B.; Sezer, P.; Oztop, M.H.; Alpas, H. Improving the Recovery of Phenolic Compounds from Spent Coffee Grounds (SCG) by Environmentally Friendly Extraction Techniques. Molecules 2021, 26, 613. https://doi.org/10.3390/

molecules 26030613

\section{Academic Editor:}

Concepción Pérez-Lamela

Received: 20 December 2020

Accepted: 21 January 2021

Published: 25 January 202

Publisher's Note: MDPI stays neutra with regard to jurisdictional claims in published maps and institutional affiliations.

Copyright: (c) 2021 by the authors. Licensee MDPI, Basel, Switzerland. This article is an open access article distributed under the terms and conditions of the Creative Commons Attribution (CC BY) license (https:// creativecommons.org/licenses/by/ $4.0 /)$.

\begin{abstract}
The aim of this study was to investigate and compare the effects of different extraction techniques (high hydrostatic pressure-assisted extraction (HHPE), ultrasound-assisted extraction (UAE), and classical solvent extraction (CSE)) on phenolic compounds from spent coffee grounds (SCG). Different HHPE parameters (300, 400 and $500 \mathrm{MPa}$ at $25{ }^{\circ} \mathrm{C}$ for 5, 10 and $15 \mathrm{~min}$ ) and UAE parameters $\left(40 \%, 50 \%\right.$, and $60 \%$ amplitude at $25^{\circ} \mathrm{C}$ for 5,10 and $15 \mathrm{~min}$ ) were used. These techniques were compared with CSE (at $50{ }^{\circ} \mathrm{C}$ for $30 \mathrm{~min}$ ) according to total phenolic content (TPC), antioxidant activity (AA), high-performance liquid chromatography (HPLC), scanning electron microscopy (SEM), and infrared (IR) spectroscopy. The results showed that eco-friendly techniques increased the TPC and AA compared to CSE and morphological changes were verified by SEM results. Furthermore, chlorogenic and caffeic acid were also quantified by using HPLC. Chlorogenic acid was found as the main phenolic compound in spent coffee grounds (SCG). The highest chlorogenic acid was detected as $85.0 \pm 0.6 \mathrm{mg} / \mathrm{kg} \mathrm{FW}$ with UAE at $60 \%$ amplitude for $15 \mathrm{~min}$. In brief, for the extraction of phenolic compounds from waste SCG eco-friendly techniques such as HHPE and/or UAE were more convenient than CSE.
\end{abstract}

Keywords: spent coffee grounds (SCG); phenolic compounds; high hydrostatic pressure-assisted extraction (HHPE); ultrasound-assisted extraction (UAE)

\section{Introduction}

Food waste is defined as any food industry outputs that are neither used for defining end-products nor for alternative purposes such as recycling [1]. A huge amount of food waste is generated every day and it is assumed that up to one-third of the food produced is wasted around the world. Therefore, food waste valorization is important and it is in the core of many studies [2]. Coffee is not only one of the most famous beverages but also it is the second most commercialized product across the world [3]. Spent coffee ground (SCG) is the main waste of processing roasted coffee powder in hot water or steam $[4,5]$. In recent years, there has been many studies related to the presence of phytochemicals in SCG, therefore SCG might be a source of valuable waste products because of the presence of mainly phenolic compounds such as caffeic and chlorogenic acids which might be used as natural antioxidants, in different industries such as food, cosmetics and pharmaceuticals [4-8].

In the extraction processes, choosing the appropriate extraction method is important [9]. Conventional extraction techniques such as solvent extraction need a lot of time, solvent and energy [10]. Therefore, the development and the usage of environmentally friendly extraction methods have become popular due to their reduced solvent consumption, decreased energy usage, shorter operation time and higher extraction yield [11-13]. Some of these techniques are high hydrostatic pressure-assisted extraction (HHPE) and 
ultrasound-assisted extraction (UAE). High hydrostatic pressure is a novel technique that is performed between 100 and $900 \mathrm{MPa}$ to destroy microorganisms, vegetative cells and enzymes to extend the shelf life of food products [14]. It is commonly used in the food industry as an alternative method to heat treatment $[15,16]$. In HHPE, a large differential pressure gradient is obtained between the interior and exterior cell membranes that causes rapid permeation [17]. Also, HHPE can be performed at room temperature (cold extraction) and this prevents the degradation of heat-sensitive compounds [18]. On the other hand, UAE, considered as a green extraction technique, basically involves using sound waves within the frequency range of $20 \mathrm{kHz}$ to $100 \mathrm{MHz}$ [19]. This technique has already been used for biologically active compounds because of the decreased extraction time, low solvent consumption and improved efficiency [20]. During UAE, cavitation occurs which produces bubbles during the period of negative pressure, which are then compressed causing their collapse. Then, solid cell walls are disrupted facilitating the release of bioactive compounds [21].

To the best of our knowledge, the application of HHPE and UAE on the polyphenol extraction from SCG has not been reported simultaneously. Hence, the aim of this study was to: (i) investigate the effects of eco-friendly extraction techniques (such as HHPE and UAE) on the extraction of spent coffee grounds (SCG) (ii) find the effect of extraction parameters of these techniques on the extraction of phenolic compounds from SCG (iii) to compare these techniques with conventional solvent extraction (CSE) by examining on total phenolic content, antioxidant activity, IR spectra, scanning electron microscopy (SEM) images and high-performance liquid chromatography (HPLC).

\section{Results and Discussion}

\subsection{Total Phenolic Content (TPC)}

The total phenolic content (TPC) results of the different extraction techniques are shown in Figure 1. As seen in the figure, HHPE and UAE treatments increased the TPC content compared to CSE. UAE-treated samples at $60 \%$ amplitude for $15 \mathrm{~min}$ had the highest TPC (9.51 $\pm 0.06 \mathrm{mg}$ GAE/FW). TPC was increased significantly $(p \leq 0.05)$ with UAE amplitude and time. When the amplitude was increased, a higher amplitude of waves traveling through the liquid media occurred and a large number of bubbles were created that crumbled more violently with enhanced cell disruption and the release of intracellular components [22]. Caballero-Galván et al. [23] also reported that UAE increased the TPC compared to solvent and soxhlet extraction which is parallel to our findings.

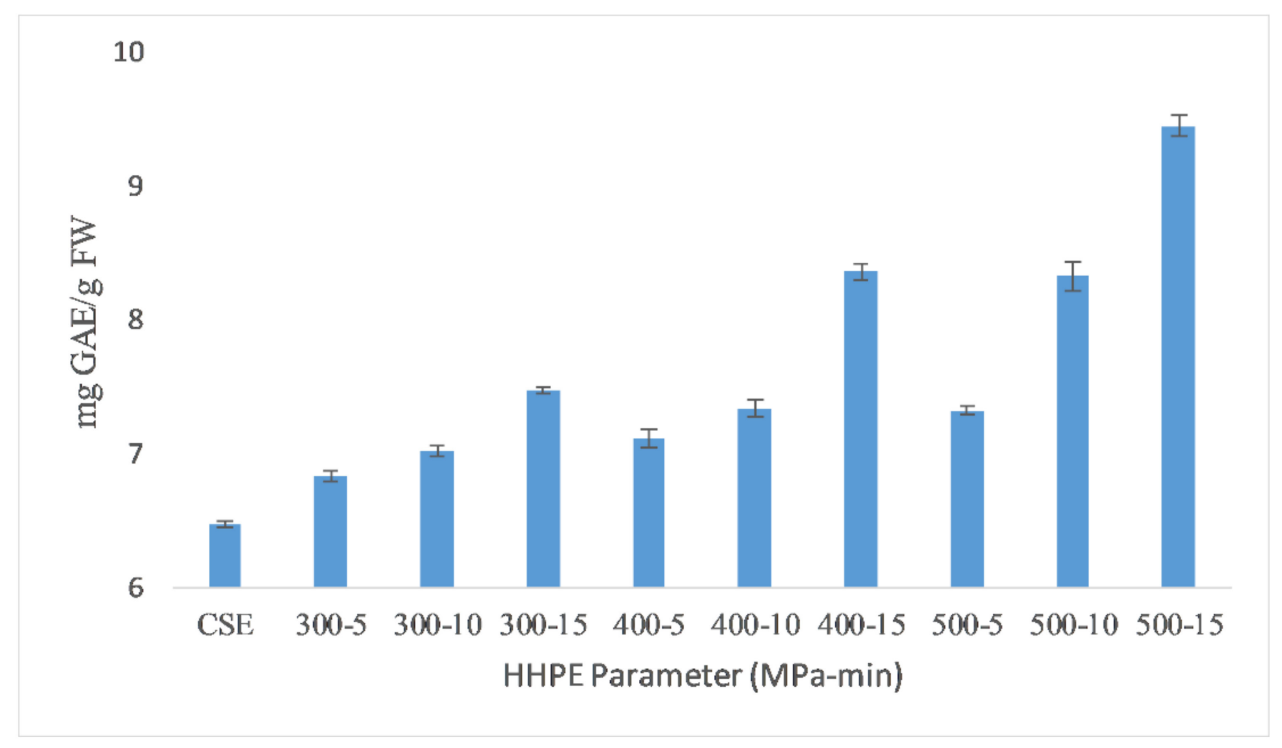

(A)

Figure 1. Cont. 


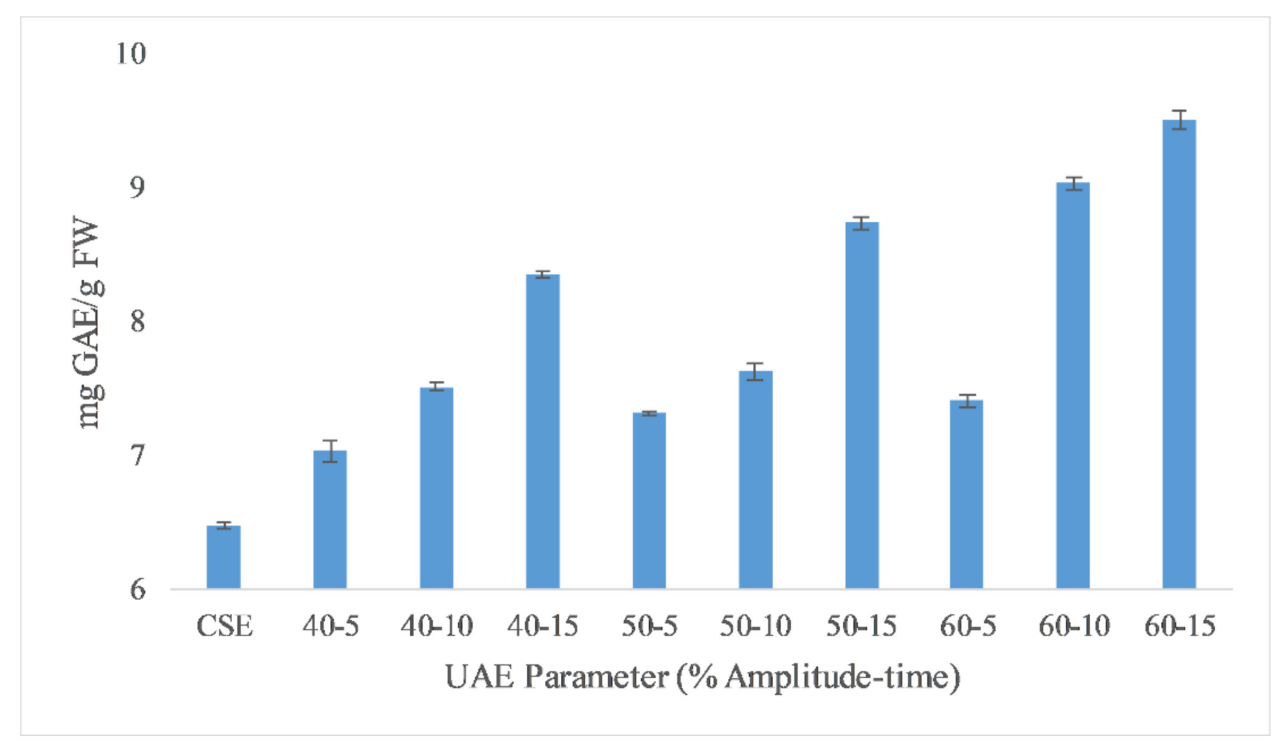

(B)

Figure 1. TPC results of different extraction techniques (A) HHPE treatment (B) UAE.

HHPE increased TPC significantly $(p \leq 0.05)$ as the pressure and time were increased, affecting the hydrophobic bonds in cellular membranes and resulting in an increase on the mass transfer rate and accordingly leading to an increase in the TPC content $[9,24]$. Higher pressure levels favor solvent penetration into the cells and more phenolics were extracted. In addition, longer treatment times resulted in an increase in the amount of phenolic substances obtained. Similar results were also reported in literature with Manuka honey (200, 400 and $600 \mathrm{MPa}$ for 5, 10 and $15 \mathrm{~min}$ ), sour cherry pomace (400 and $500 \mathrm{MPa}$ for 1,5 , and $10 \mathrm{~min}$ ) and olive pomace ( 300 and $600 \mathrm{MPa}$ for 5 and $10 \mathrm{~min})[9,25,26]$. The extraction of phenolic compound from SCG has been widely studied by other techniques. It was reported that TPC value of the low-grade green coffee and spent coffee was between 1.0 and $4.5 \mathrm{mg} \mathrm{GAE} / \mathrm{g}$ dry weight in a water bath $\left(70^{\circ} \mathrm{C}\right)$ for $10 \mathrm{~min}$ [27]. Ballesteros et al. [5] found that the optimum autohydrolysis conditions to extract phenolic compounds from SCG was $40.36 \mathrm{mg}$ GAE/g SCG at $200{ }^{\circ} \mathrm{C}$ for $50 \mathrm{~min}$ with a liquid/solid ratio of $15 \mathrm{~mL} / \mathrm{g}$. The result of this study was much higher than our findings due to extraction temperature and time.

\subsection{Antioxidant Activity (AA)}

\subsubsection{DPPH Assay}

DPPH assay results of different extraction techniques are reported in Figure 2 to depict AA. Like the TPC results, CSE had the lowest DPPH assay activity and HHPE and UAE caused an increase in DPPH assay activity. For HHPE, the antioxidant activity increased statistically significantly $(p \leq 0.05)$ with increasing pressure and time. Furthermore, UAE also increased antioxidant activity statistically significantly with amplitude and time $(p \leq 0.05)$. Generally, the antioxidant activity is proportional to the total phenolic content (TPC) of the extracts [28]. According to Pearson correlation, a strong correlation (0.816) was also found between antioxidant activity and TPC. Caballero-Galván et al. [24] showed that UAE increased the AA of SCG compared to solvent and Soxhlet extraction and this result also agrees with our findings. Okur et al. [26] also reported that HHPE showed higher AA than CSE in sour cherry pomace. 


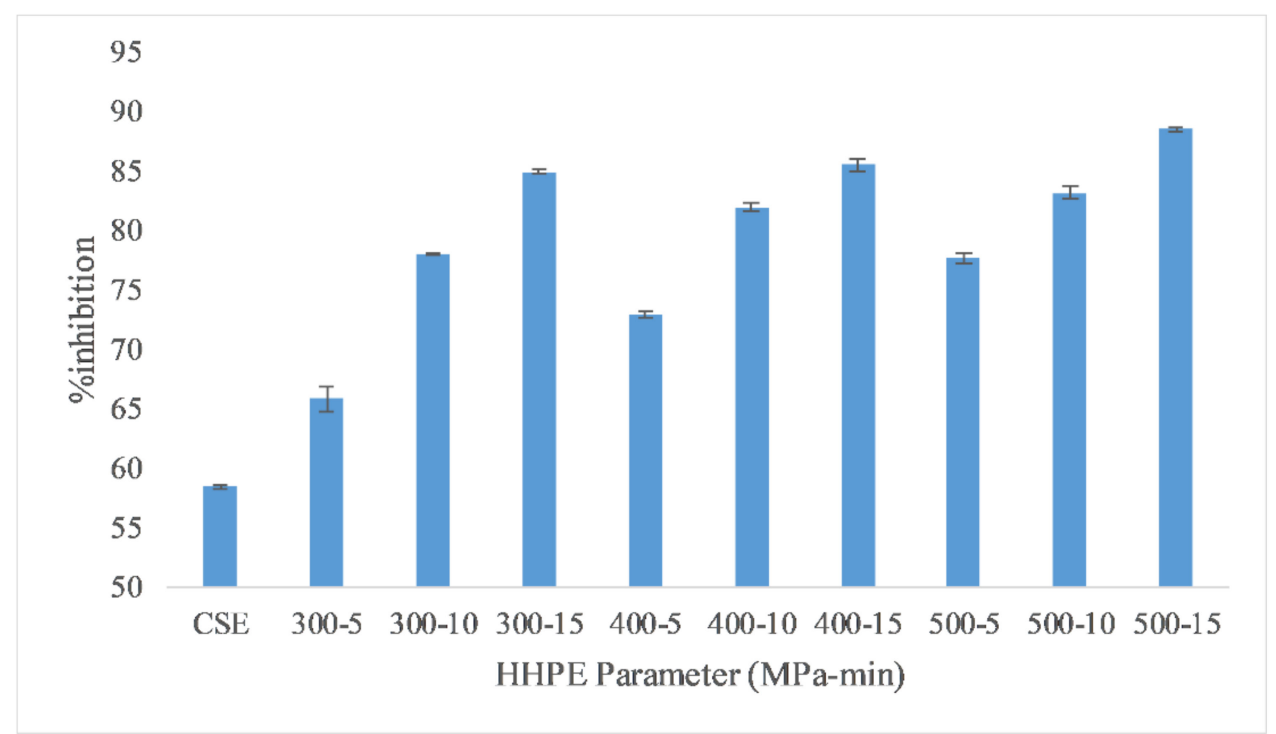

(A)

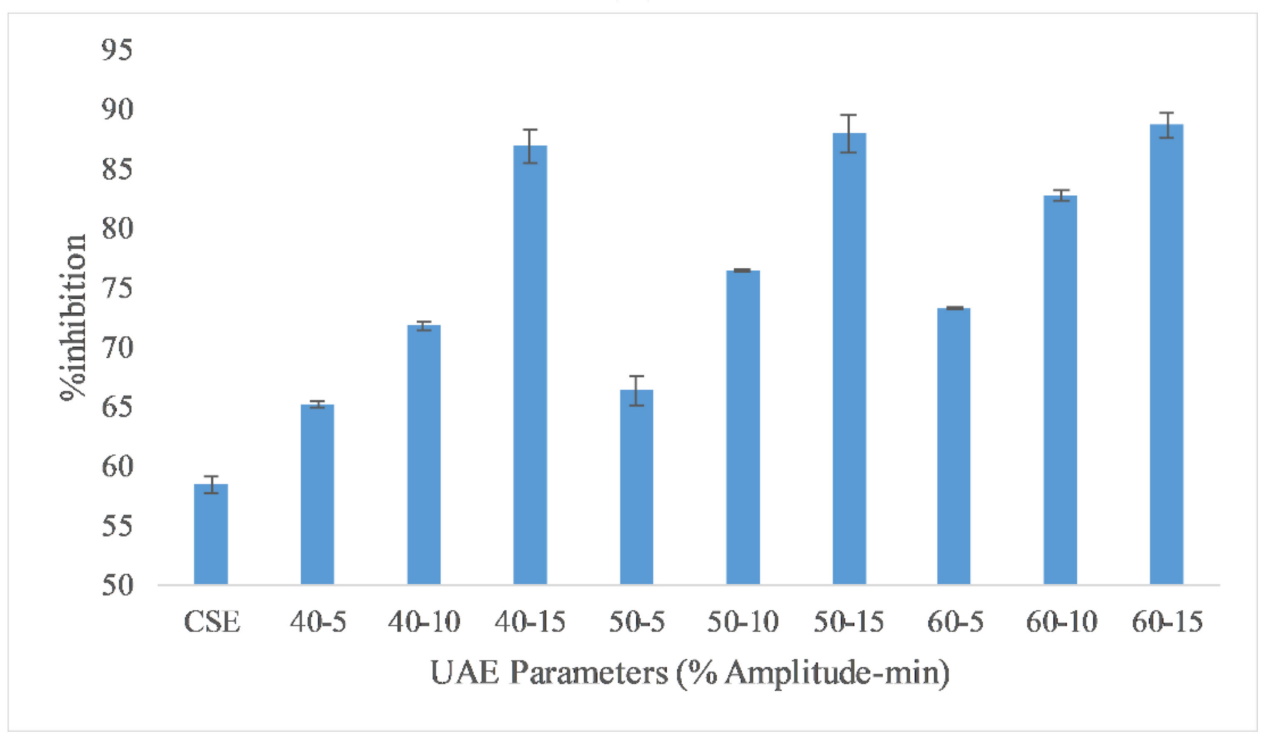

(B)

Figure 2. DPPH assay results of (A) HHPE treatment (B) UAE.

\subsubsection{Ferric Reducing Antioxidant Power (FRAP)}

Ferric reducing antioxidant power (FRAP) is a useful method to measure the antioxidant activity (AA) of extracts due to its low cost, speed and technical simplicity [29]. The FRAP results of the different extraction techniques are reported in Figure 3. The lowest antioxidant activity was found in CSE at $0.57 \pm 0.05 \mathrm{mmol} \mathrm{FeSO}_{4} / 100 \mathrm{~g}$ FW while the highest antioxidant activity (AA) was found in UAE at $60 \%$ amplitude for $15 \mathrm{~min}$ as $0.89 \pm 0.04 \mathrm{mmol} \mathrm{FeSO}_{4} / 100 \mathrm{~g}$ FW. According to the Pearson correlation, a strong correlation (0.9) was detected between AA and TPC. Also, eco-friendly techniques gave more antioxidant activity than CSE. In HHPE, the volume of a system tends to reduce whwhen the pressure is increased from atmospheric pressure to operating temperature. During the HHPE process, the extraction solvent enters into cells to interact with the bioactive components. Furthermore, the permeability of pressurized cells increases. Thus, more phenolic compounds permeate out into the solvent when the operating pressure is increased and the more solvent enters the cells [29]. At UAE, the hydrodynamic force causes the disruption 
of the cell walls. When the amplitude is increased, more extensive cavitation occurs and this improves the release rate of phenolic compounds from the sample into the solvent [30].

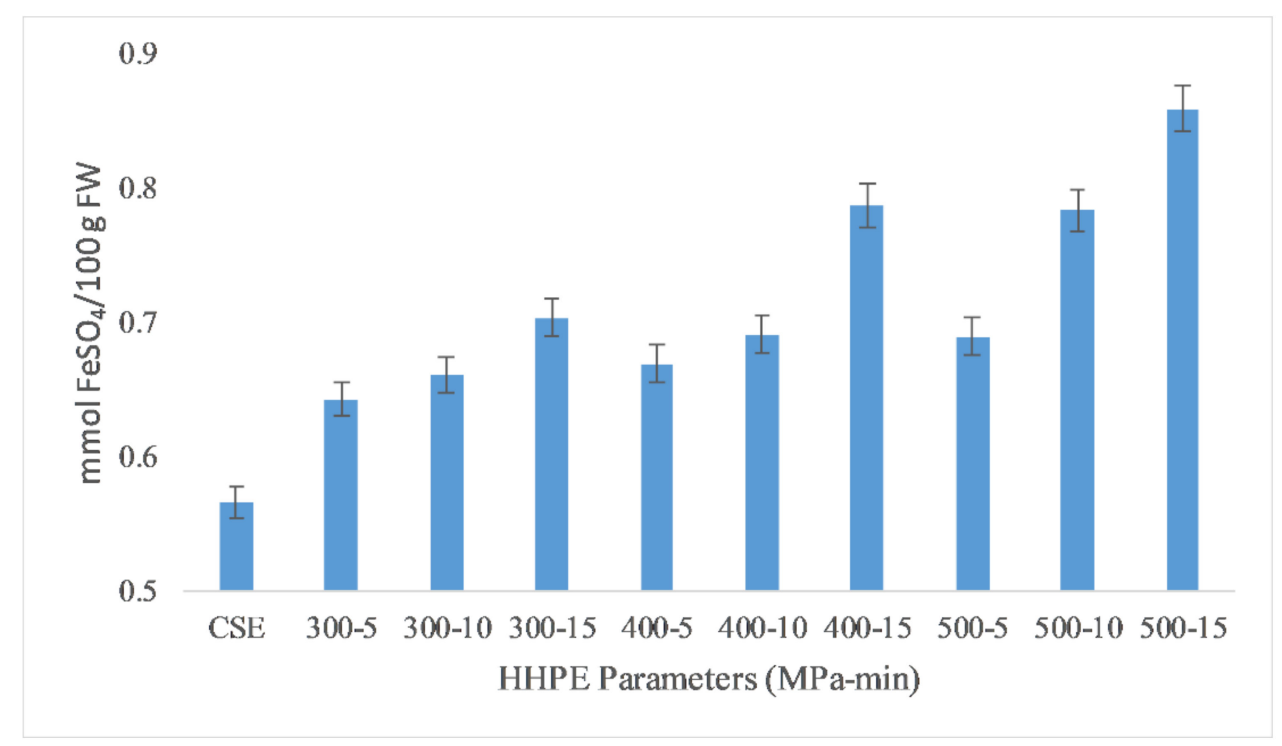

(A)

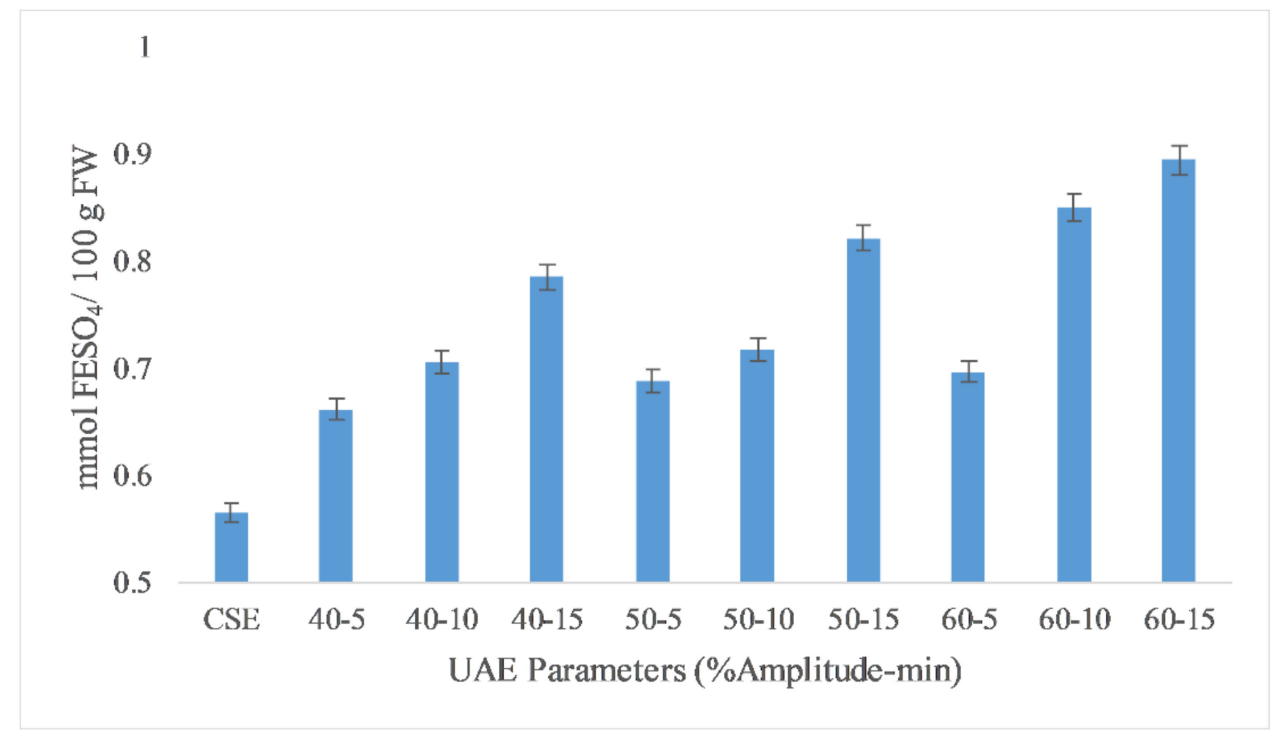

(B)

Figure 3. FRAP results of different extraction techniques (A) HHPE treatment (B) UAE.

\subsection{High Performance Liquid Chromatography (HPLC)}

The samples were chosen for HPLC analysis according to the highest TPC and AA results with each extraction technique. For these samples, chlorogenic and caffeic acid content were detected and quantified by using HPLC. Chromatograms of the standards and phenolics from extracts obtained using HHPE, UAE and CSE are shown in Figure 4. The quantities of the phenolic compounds are reported in Table 1. Much more chlorogenic acid than caffeic acid was obtained with all the extraction methods. It was also reported as the major compound in SCG in the literature, [31-33]. The highest chlorogenic acid content was found in UAE at $85.0 \pm 0.6 \mathrm{mg} / \mathrm{kg} \mathrm{FW}$, while the lowest content was found in CSE at $24.0 \pm 0.3 \mathrm{mg} / \mathrm{kg}$ FW. Like chlorogenic acid content, the highest caffeic acid content was found in UAE $(6.1 \pm 0.2 \mathrm{mg} / \mathrm{kg} \mathrm{FW})$ and the lowest caffeic acid was found in CSE $(2.2 \pm 0.1 \mathrm{mg} / \mathrm{kg} \mathrm{FW})$. Furthermore, it was obvious that the eco-friendly techniques 
both increased the caffeic and chlorogenic acid contents significantly $(p \leq 0.05)$. UAE had higher caffeic and chlorogenic acid content as compared to HHPE. This result also matched the TPC and antioxidant activity results. At UAE, acoustic cavitation phenomena and the bubbles generated damaged the cell walls. On the other hand, in HHPE, the rapidly increasing pressure caused an acceleration of cell wall breakage and solvent penetration to the cells. In the literature, more phenolic content was observed at UAE than HHPE for sour cherry pomace, olive pomace and tomato peel waste [9,26,34]. Caballero-Galván et al. [24] indicated that UAE increased the chlorogenic and caffeic acid content comparing to solvent extraction and Soxhlet extraction. This result matches our findings.
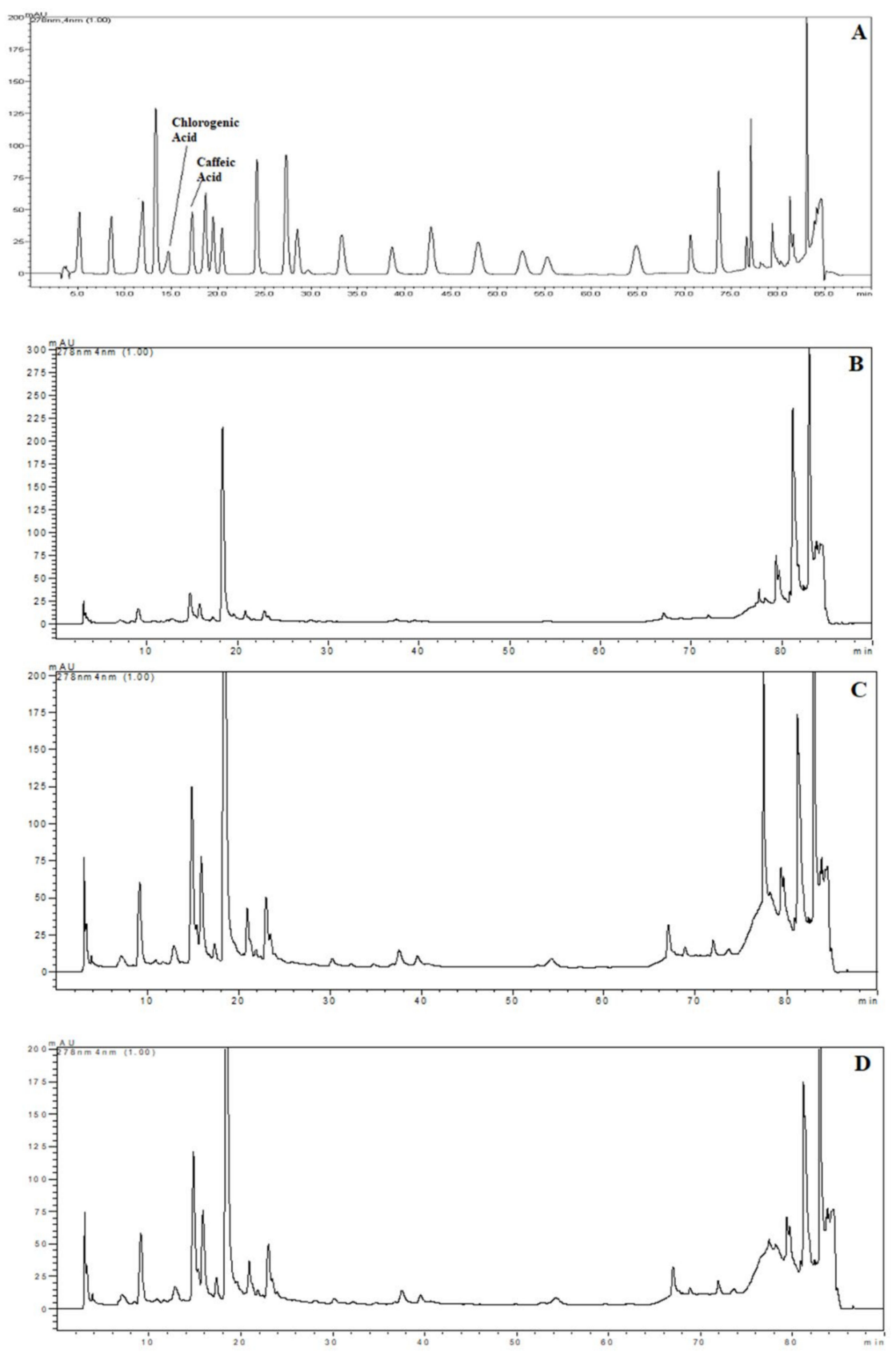

Figure 4. HPLC chromatograms (A) Chromatogram of phenolic standards (B) Chromatogram of phenolic from SCG extracted by CSE (C) Chromatogram of phenolic from SCG extracted by HHP treatment (500 MPa for 15 min) (D) Chromatogram of phenolic from SCG extracted by UAE (60\% Amplitude for $15 \mathrm{~min}$ ). 
Table 1. Individual phenolic compounds from SCG extracted by CSE, HHPE (500 MPa for $15 \mathrm{~min}$ ) and UAE (60\% Amplitude for $15 \mathrm{~min})$.

\begin{tabular}{ccc}
\hline & Chlorogenic Acid & Caffeic Acid \\
\hline CSE & $24.0 \pm 0.3^{\mathrm{c}}$ & $2.2 \pm 0.1^{\mathrm{c}}$ \\
HHPE & $81.2 \pm 1.1^{\mathrm{b}}$ & $5.4 \pm 0.5^{\mathrm{a}, \mathrm{b}}$ \\
UAE & $85.0 \pm 0.6^{\mathrm{a}}$ & $6.1 \pm 0.2^{\mathrm{a}}$ \\
\hline
\end{tabular}

$\overline{\mathrm{a}-\mathrm{c}}$ Different small letters show significant differences $(p \leq 0.05)$.

\subsection{Infrared (IR) Spectroscopy}

The infrared (IR) spectroscopy analysis of SCG extractions using different techniques is shown in Figure 5. According to the results, there was no destruction of the chemical structures of phenolic compounds caused by the environmentally-friendly extraction techniques HHPE and UAE or CSE. The broad band around $3400 \mathrm{~cm}^{-1}$ corresponds to $\mathrm{OH}$-stretching with a minor contribution of $-\mathrm{NH}$ functional groups [35]. The bands at $1523 \mathrm{~cm}^{-1}$ and $1655 \mathrm{~cm}^{-1}$ correspond to the $\mathrm{C}=\mathrm{C}$ vibrations of aromatic rings from lignin moieties and the $\mathrm{C}=\mathrm{C}$ vibrations of unsaturated lipids and fatty acids, respectively [36]. The sharp peaks at $2925 \mathrm{~cm}^{-1}$ and $2855 \mathrm{~cm}^{-1}$, showing the presence of methyl and methylene groups, respectively, sre related to the asymmetric and symmetric stretching of $\mathrm{C}-\mathrm{H}$ bonds in aliphatic chains [37]. In the literature, the presence of caffeine was explained with these peaks [38]. The bands between $1061 \mathrm{~cm}^{-1}$ and $1376 \mathrm{~cm}^{-1}$ are related to chlorogenic acids formed by quinic acid and trans-cinnamic acids; respectively [39]. Moreover, the bands between $900 \mathrm{~cm}^{-1}$ and $1400 \mathrm{~cm}^{-1}$ show different types of vibrations consisting of the $\mathrm{C}-\mathrm{H}$, C-O C, C-N and P-O bonds characteristic of polysaccharides [40]. Although it was difficult to detect the corresponding bands due to either to chlorogenic acids or polysaccharides, HPLC analysis of this study showed that the extracts contained chlorogenic acid.

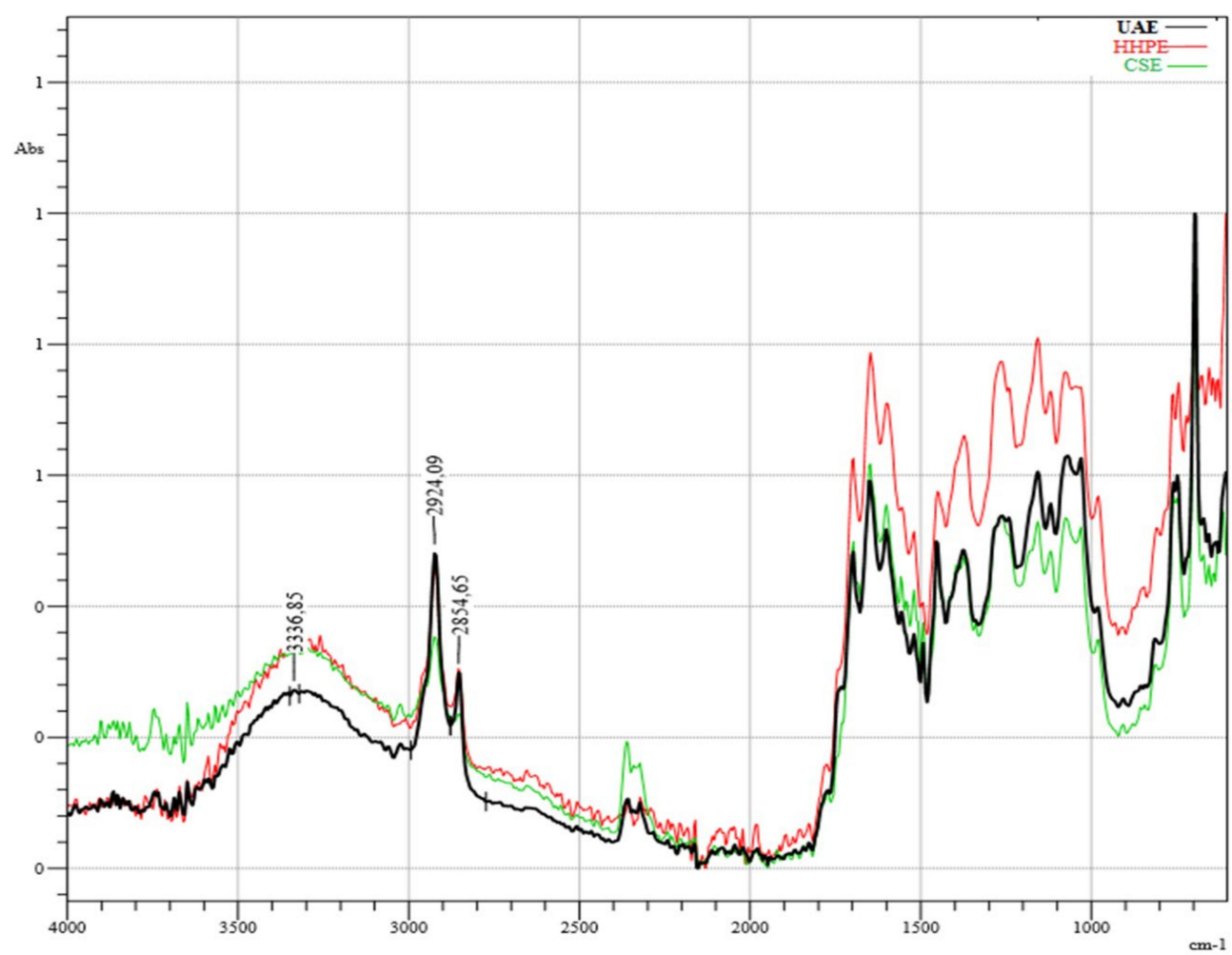

Figure 5. Infrared (IR) Spectrum results. UAE (60\% Amplitude for $15 \mathrm{~min}$ ), HHPE (500 MPa for $15 \mathrm{~min})$, CSE. 


\subsection{Morphological Analysis}

The morphological changes of different extraction techniques were characterized by scanning electron microscopy (SEM) analysis and the results are depicted in Figure 6. After CSE and HHPE, no cell damage was observed (Figure 6A,B). However, more contact area was detected and this might increase the phenolic transfer rate of HHPE. A similar result was also reported by our research group for the extraction of sour cherry pomace by different extraction methods [26]. For UAE, cell damage was observed compared to CSE and HHPE (Figure 6C). This result has also been shown in the literature [26,41,42]. At UAE treatment, acoustic cavitation occurs and this leads to micro fissures and microchannels on the matrix surface so UAE increases the transfer of phenolic compounds into the solvent $[43,44]$. In brief, SEM analysis indicated that the eco-friendly techniques caused an increase in the release of phenolics comparing to CSE basically due to the morphological changes.

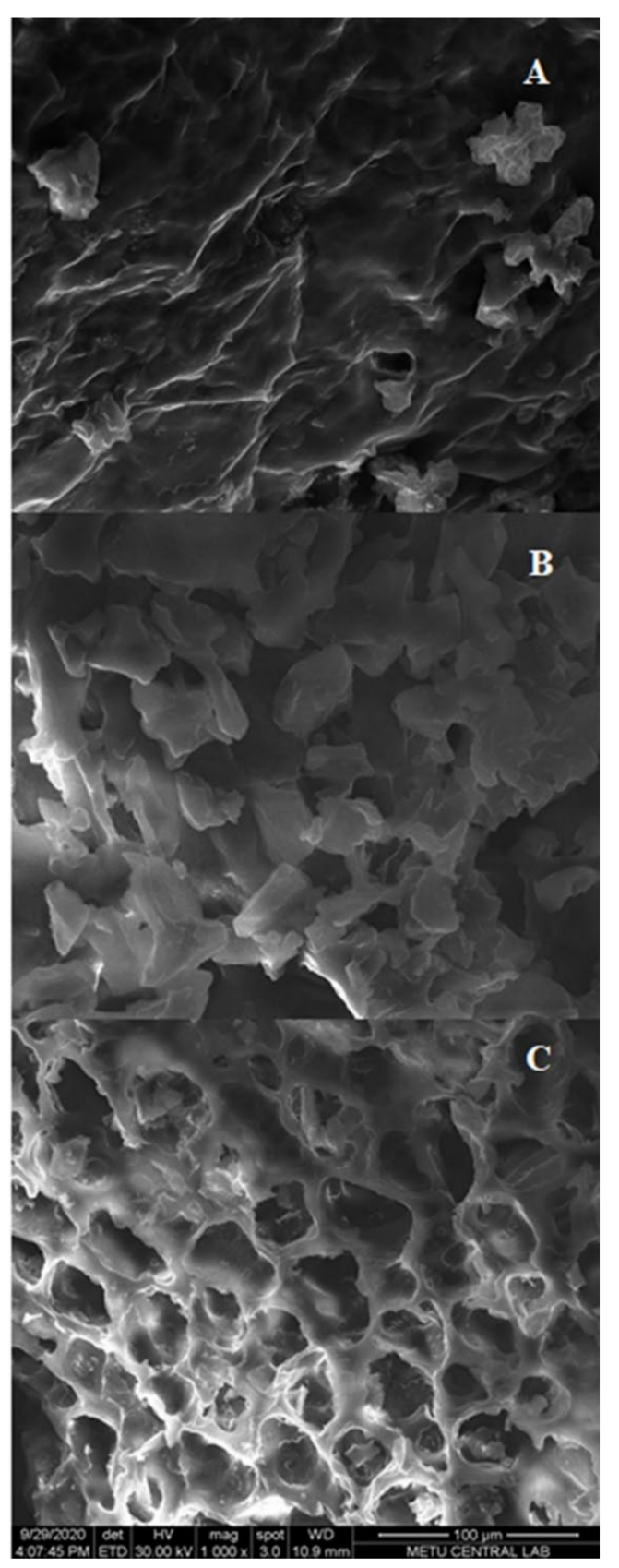

Figure 6. SEM results (A) CSE (B) HHPE (500 MPa for $15 \mathrm{~min}$ ) (C) UAE (60\% Amplitude for $15 \mathrm{~min}$ ). 


\section{Materials and Methods}

\subsection{Materials}

Spent coffee grounds (SCG, coffee Arabica) was provided from a local branch of a national coffee chain located at Middle East Technical University Campus in Ankara, Turkey (September 2020) and stored at $-18{ }^{\circ} \mathrm{C}$ until usage. The initial moisture content of the SCG was $22.8 \pm 0.5 \%$.

\subsection{Conventional Solvent Extraction (CSE)}

The conventional solvent extraction (CSE) technique was applied according to Altemimi et al. [45] with some modifications. In brief, a SCG-\% 80 methanol solution $(10 \% w / v)$ was prepared. Then, the mixture was placed in a water bath (WiseCircu, Seoul, Korea) at $50{ }^{\circ} \mathrm{C}$ for $30 \mathrm{~min}$ to solubilize phenolic compounds from SCG. Then, the mixture was filtered by filter paper (Whatman No.1), and the extract was stored at $4{ }^{\circ} \mathrm{C}$ until further analysis. CSE technique was indicated as control when presenting the results.

\subsection{High Hydrostatic Pressure-Assisted Extraction (HHPE)}

High Hydrostatic Pressure-Assisted Extraction (HHPE) treatment was applied by using 760.0118 type pressure equipment (SITEC-Sieber Engineering AG, Zurich, Switzerland). The vessel volume was $100 \mathrm{~mL}$ with diameter $24 \mathrm{~mm}$ and length $153 \mathrm{~mm}$. A built-in heating-cooling system (Huber Circulation Thermostat, Offenburg, Germany) was used to control treatment temperature measured by thermocouple. The equipment consists of a pressurization chamber, two end closures, a means for restraining the end closures, a pressure pump, a hydraulic unit, and a temperature control device. A mixture of water and glycol was used as pressure-transmitting medium and it was heated prior to pressurization to reach the treatment temperature. The pressure release time was less than $20 \mathrm{~s}$ for each so the pressurization time reported in this study did not contain the pressure increase and release times. Prepared SCG-\% 80 methanol solutions $(10 \% w / v)$ were pressurized in $25 \mathrm{~mL}$ sterile polyethylene cryotubes (LP Italiana SPA, Milano, Italy) at 300, 400, and $500 \mathrm{MPa}$ for 5, 10, and $15 \mathrm{~min}$ at constant temperature as $25^{\circ} \mathrm{C}$. After HHPE treatment, filtration of the mixture was performed by filter paper (Whatman No.1), and the extract was stored at $4{ }^{\circ} \mathrm{C}$ till further analysis.

\subsection{Ultrasound-Assisted Extraction (UAE)}

Ultrasound-Assisted Extraction (UAE) treatment was applied with a Heilscher UP400S system (Dr.Heilscher GmbH, Teltow, Germany) at $24 \mathrm{kHz}, 400 \mathrm{~W}$. At all UAE treatments, a titanium alloy sonotrode (H3, Dr. Heilscher $\mathrm{GmbH}$ ) with ID $3 \mathrm{~mm}$ was used. To keep constant temperature of the mixture for all UAE treatments, ice bath was used to keep the constant temperature of the mixture at roughly $25 \pm 1{ }^{\circ} \mathrm{C}$. Prepared SCG-\% 80 methanol solutions $(10 \% w / v)$ were treated at $25 \mathrm{kHz}$ with different amplitudes (40,50, and 60\%) at different treatment times $(5,10$, and $15 \mathrm{~min})$. The probe was put into the solution from the center in such a way that the height was $1 / 3$ of the sample height from the bottom. After treatment, the mixture was filtered by using filter paper (Whatman No.1) and the extract was stored at $4{ }^{\circ} \mathrm{C}$ till further analysis.

\subsection{Total Phenolic Content (TPC)}

The Folin-Ciocalteu assay was performed to calculate the TPC of samples according to Okur et al. [26]. In brief, $0.75 \mathrm{~mL}$ Folin-Ciocalteu solution $(10 \% v / v)$ was added to $100 \mu \mathrm{L}$ extract. Next, the mixture was kept for $5 \mathrm{~min}$ at room temperature, and $0.75 \mathrm{~mL}$ of sodium carbonate solution $(7.5 \mathrm{~g} / \mathrm{L})$ was added. Then, the mixture was kept for $1 \mathrm{~h}$ in the dark. Finally, the absorbance of the samples was measured at $725 \mathrm{~nm}$ by using spectrophotometer (Shimadzu UV-1700, Tokyo, Japan). The gallic acid calibration curve was used as a standard to quantify the TPC value of samples, and TPC results were expressed as mg gallic acid equivalent (GAE)/100 $\mathrm{g}$ fresh weight (FW). 


\subsection{Antioxidant Activity (AA)}

\subsubsection{DPPH Assay}

An aliquot of $100 \mu \mathrm{L}$ extract was mixed with $3.9 \mathrm{~mL}$ of $0.1 \mathrm{mM}$ prepared 1, 1-diphenyl2-picrylhydrazyl (DPPH) solution prepared with $80 \%$ methanol solution and the mixture was stored in dark at room temperature for $30 \mathrm{~min}$. Then, the absorbance of the mixture was measured at $517 \mathrm{~nm}$ (Shimadzu UV-1700). Antioxidant activity results were given as $\%$ inhibition of DPPH activity and the results were calculated according to the following formula [26]:

$$
\text { \%inhibition of DPPH activity }=[1-(\text { As } / \text { Ac })] \times 100
$$

where As is the absorbance value of the sample, Ac is the absorbance value of control.

\subsubsection{Ferric Reducing Antioxidant Power (FRAP)}

The total antioxidant activity (AA) was also performed by using the ferric reducing ability of plasma FRAP assay by Benzie and Strain, [46]. The FRAP assay utilizes antioxidants as reductants in a redox-linked colorimetric method. At low $\mathrm{pH}$, the reduction of ferric tripyridyl triazine (Fe III TPTZ) complex to ferrous form was detected by measuring the change in absorption at $593 \mathrm{~nm}$. Three $\mathrm{ml}$ of FRAP reagent [(a) acetate buffer $(300 \mathrm{mM}$ $\mathrm{pH}$ 3.6) was prepared by weighing $3.1 \mathrm{~g}$ sodium acetate trihydrate $\left(\mathrm{CH}_{3} \mathrm{COONa} \cdot 3 \mathrm{H}_{2} \mathrm{O}\right)$ and adding $16 \mathrm{~mL}$ of glacial acetic acid to make the volume to $1 \mathrm{~L}$ with distilled water. (b) TPTZ (2, 4, 6-tripyridyl-s- triazine) (MW 312.34) $10 \mathrm{mM}$ in $40 \mathrm{mM} \mathrm{HCl}$ (MW 36.46) (c) $\mathrm{FeCl}_{3} \cdot 6 \mathrm{H}_{2} \mathrm{O}$ (MW 270.30) $20 \mathrm{mM}$. The FRAP reagent was prepared by mixture of $\mathrm{a}, \mathrm{b}$ and $c$ with the ratio of 10:1:1 respectively and mixed with $100 \mu \mathrm{L}$ sample and absorbance at $593 \mathrm{~nm}$ was measured at $\mathrm{t}=0 \mathrm{~min}$ after thorough vortexing. Then, samples were put in water bath (WiseCircu) at $37^{\circ} \mathrm{C}$ and absorbance of samples were again measured after $4 \mathrm{~min}$. The standard ferrous sulfate solution $\left(\mathrm{FeSO}_{4}\right)$ curve was used as a standard to quantify the antioxidant activity of samples, and the FRAP results were calculated as mmol $\mathrm{FeSO}_{4} / 100 \mathrm{~g}$ fresh weight (FW).

\subsection{Scanning Electron Microscopy (SEM)}

SEM analysis was performed to find the morphological modifications after different extraction techniques, by using electron microscope (Nova NanoSEM 430, FEI, OR, USA). Before imaging, the samples were lyophilized for two days (Zhejiang ValueMechanical \& Electrical Products Co. Ltd., Wenling City, China) and coated with a thin layer of $\mathrm{Au}-\mathrm{Pd}$ at room temperature.

\subsection{Infrared Spectroscopy (IR)}

Infrared (IR) spectra were recorded using a FTIR spectrometer (Shimadzu Corporation) to assess the changes in chemical structures of phenolic compounds caused by extraction techniques. The lyophilized sample was placed over the attenuated total refection (ATR) crystal and the FTIR spectra was measured in the $4000 \mathrm{~cm}^{-1}$ to $600 \mathrm{~cm}^{-1}$ range by the addition 32 scans with a resolution of $2 \mathrm{~cm}^{-1}$.

\subsection{High-Performance Liquid Chromatography (HPLC)}

High-performance liquid chromatography (HPLC, Shimadzu Corporation) was performed in different treated samples to quantify caffeic acid and chlorogenic acid. HPLC system included an autosampler (SIL-10ADvp), a quaternary pump (LC-10ADvp) and a diode array detector (DAD). All the samples were passed through $0.45 \mu \mathrm{m}$ nylon filter membranes. A Simultaneous determination of chlorogenic acid and caffeic acid, was performed in a Shimadzu HPLC. An Eclipse XDB-C18 column (Agilent197, Palo Alto, CA, USA) $(250 \times 4.60 \mathrm{~mm})$ with a particle size of $5 \mu \mathrm{m}$ was used. The mobile phase included $3 \%$ acetic acid in water (A) and methanol (B). Extracts were eluted based on following steps: the gradient was started with $7 \%$ B to reach $28 \%$ B at $20 \mathrm{~min}, 25 \%$ B at $28 \mathrm{~min}$, $30 \% \mathrm{~B}$ at $35 \mathrm{~min}, 30 \% \mathrm{~B}$ at $50 \mathrm{~min}, 33 \% \mathrm{~B}$ at $60 \mathrm{~min}, 42 \% \mathrm{~B}$ at $62 \mathrm{~min}, 50 \% \mathrm{~B}$ at $70 \mathrm{~min}$, $70 \% \mathrm{~B}$ at $73 \mathrm{~min}, 80 \% \mathrm{~B}$ at $75 \mathrm{~min}, 100 \% \mathrm{~B}$ at $80 \mathrm{~min}$ and $7 \% \mathrm{~B}$ at $81 \mathrm{~min}$. The column 
temperature and flow rate were $30^{\circ} \mathrm{C}$ and $0.8 \mathrm{~mL} / \mathrm{min}$ respectively. The phenolics were found and quantified at $278 \mathrm{~nm}$ [47]. For the quantification of SCG, the external standards were used. The good linearity (correlation coefficient values $\left(R^{2}>0.999\right)$ was achieved in a relatively wide concentration ranging from 0 to 2 ppm for chlorogenic acid and caffeic acid. Regression equation, $\mathrm{R}^{2}$ values, the limit of detection (LOD) and quantification (LOQ) values were summarized in Table 2.

Table 2. Calibration data for chlorogenic acid and caffeic acid.

\begin{tabular}{ccccc}
\hline Compound & $\begin{array}{c}\text { Regression Equation } \\
(\mathbf{y}=\mathbf{a x}+\mathbf{b})\end{array}$ & $\mathbf{\mathbf { R } ^ { 2 }}$ & LOD (ppm) & LOQ (ppm) \\
\hline Chlorogenic acid & $-1568.37 x+31,041.23$ & 0.99994 & 0.02 & 0.07 \\
Caffeic Acid & $600.75 x+76,114.15$ & 0.99948 & 0.05 & 0.14 \\
\hline
\end{tabular}

\subsection{Statistical Analysis}

SigmaPlot (Ver.14, Systat Software Inc., San Jose, CA, USA) was used for data analysis. Analysis of Variance (ANOVA) was carried out to detect the differences between samples. Furthermore, Tukey's multiple range test was used to interpret significant differences between the experimental mean values $(p<0.05)$.

\section{Conclusions}

To the best of our knowledge, this is the first study reporting the effect of environmentallyfriendly extraction techniques on the recovery of phenolic compounds from waste spent coffee grounds (SCG). Both eco-friendly extraction methods (HHPE and UAE) increased the TPC and AA significantly $(p \leq 0.05)$. Also, IR results indicated that there was no significant difference in the chemical structures of the phenolic compounds recovered using either UAE or HHPE as compared to those recovered by CSE. The morphological changes taking place during these methods led to an increase in the mass transfer of phenolic substances. According to HPLC results, HHPE and UAE increased the chlorogenic and caffeic acid content. Among these, UAE produced more chlorogenic and caffeic acid than HHPE as supported by TPC and AA results. In brief, our research shows that HHPE and UAE are not only suitable and convenient but also environmentally-friendly and fast extraction methods as compared to CSE for improving the recovery of phenolic compounds from SCG waste.

Author Contributions: I.O. (Conceptualization, Formal analysis, Methodology, Writing-original draft); B.S. (Formal analysis, Writing-original draft); P.S. (Conceptualization, Formal analysis, Writingoriginal draft); M.H.O. (Methodology, Writing-review, Supervision); H.A. (Writing-review, Supervision). All authors have read and agreed to the published version of the manuscript.

Funding: This research received no external funding.

Institutional Review Board Statement: Not applicable.

Informed Consent Statement: Not applicable.

Acknowledgments: The authors would like to thank Coffee101, METU, Ankara branch for providing SCG.

Conflicts of Interest: The authors declare that there are no conflict of interest.

Sample Availability: Samples of the compounds are not available from the authors.

\section{References}

1. Du, C.; Abdullah, J.J.; Greetham, D.; Fu, D.; Yu, M.; Ren, L.; Li, S.; Lu, D. Valorization of food waste into biofertiliser and its field application. J. Clean. Prod. 2018, 187, 273-284. [CrossRef]

2. Tonini, D.; Albizzati, P.F.; Astrup, T.F. Environmental impacts of food waste: Learnings and challenges from a case study on UK. Waste Manag. 2018, 76, 744-766. [CrossRef] [PubMed] 
3. Buratti, C.; Barbanera, M.; Lascaro, E.; Cotana, F. Optimization of torrefaction conditions of coffee industry residues using desirability function approach. Waste Manag. 2018, 73, 523-534. [CrossRef] [PubMed]

4. Arauzo, P.J.; Lucian, M.; Du, L.; Olszewski, M.P.; Fiori, L.; Kruse, A. Improving the recovery of phenolic compounds from spent coffee grounds by using hydrothermal delignification coupled with ultrasound assisted extraction. Biomass Bioenergy 2020, 139. [CrossRef]

5. $\quad$ Ballesteros, L.F.; Ramirez, M.J.; Orrego, C.E.; Teixeira, J.A.; Mussatto, S.I. Optimization of autohydrolysis conditions to extract antioxidant phenolic compounds from spent coffee grounds. J. Food Eng. 2017, 199, 1-8. [CrossRef]

6. Campos-Vega, R.; Vázquez-Sánchez, K.; López-Barrera, D.; Loarca-Piña, G.; Mendoza-Díaz, S.; Oomah, B.D. Simulated gastrointestinal digestion and in vitro colonic fermentation of spent coffee (Coffea arabica L.): Bioaccessibility and intestinal permeability. Food Res. Int. 2015, 77, 156-161. [CrossRef]

7. Magalhães, L.M.; Machado, S.; Segundo, M.A.; Lopes, J.A.; Páscoa, R.N.M.J. Rapid assessment of bioactive phenolics and methylxanthines in spent coffee grounds by FT-NIR spectroscopy. Talanta 2016, 147, 460-467. [CrossRef]

8. Esquivel, P.; Jiménez, V.M. Functional properties of coffee and coffee by-products. Food Res. Int. 2012, 46, 488-495. [CrossRef]

9. Chanioti, S.; Tzia, C. Extraction of phenolic compounds from olive pomace by using natural deep eutectic solvents and innovative extraction techniques. Innov. Food Sci. Emerg. Technol. 2018, 48, 228-239. [CrossRef]

10. Fragoso, S.; Mestres, M.; Busto, O.; Guasch, J. Comparison of three extraction methods used to evaluate phenolic ripening in red grapes. J. Agric. Food Chem. 2010, 58, 4071-4076. [CrossRef]

11. Wijngaard, H.; Hossain, M.B.; Rai, D.K.; Brunton, N. Techniques to extract bioactive compounds from food by-products of plant origin. Food Res. Int. 2012, 46, 505-513. [CrossRef]

12. Zia, S.; Khan, M.R.; Shabbir, M.A.; Aslam Maan, A.; Khan, M.K.I.; Nadeem, M.; Khalil, A.A.; Din, A.; Aadil, R.M. An Inclusive Overview of Advanced Thermal and Nonthermal Extraction Techniques for Bioactive Compounds in Food and Food-related Matrices. Food Rev. Int. 2020, 1-31. [CrossRef]

13. Gałuszka, A.; Migaszewski, Z.M.; Konieczka, P.; Namieśnik, J. Analytical Eco-Scale for assessing the greenness of analytical procedures. TrAC Trends Anal. Chem. 2012, 37, 61-72. [CrossRef]

14. Alpas, H.; Kalchayanand, N.; Bozoglu, F.; Ray, B. Interactions of high hydrostatic pressure, pressurization temperature and pH on death and injury of pressure-resistant and pressure-sensitive strains of foodborne pathogens. Int. J. Food Microbiol. 2000, 60, 33-42. [CrossRef]

15. Okur, I.; Ozel, B.; Oztop, M.H.; Alpas, H. Effect of high hydrostatic pressure in physicochemical properties and in vitro digestibility of cornstarch by nuclear magnetic resonance relaxometry. J. Food Process. Eng. 2019, 1-10. [CrossRef]

16. Vallons, K.J.R.; Arendt, E.K. Effects of high pressure and temperature on the structural and rheological properties of sorghum starch. Innov. Food Sci. Emerg. Technol. 2009, 10, 449-456. [CrossRef]

17. Shouqin, Z.; Jun, X.; Changzheng, W. High hydrostatic pressure extraction of flavonoids from propolis. J. Chem. Technol. Biotechnol. 2005, 80, 50-54. [CrossRef]

18. Moreira, S.A.; Pintado, M.E.; Saraiva, J.A. Optimization of high hydrostatic pressure assisted extraction of stinging nettle leaves using response surface methodology experimental design. J. Food Meas. Charact. 2020, 14, 2773-2780. [CrossRef]

19. Kate, A.; Singh, A.; Shahi, N.C.; Pandey, J. Novel Eco-Friendly Techniques for Extraction of Food Based Lipophilic Compounds from Biological Materials. Nat. Prod. Chem. Res. 2016, 4. [CrossRef]

20. Jerman, T.; Trebše, P.; Mozetič Vodopivec, B. Ultrasound-assisted solid liquid extraction (USLE) of olive fruit (Olea europaea) phenolic compounds. Food Chem. 2010, 123, 175-182. [CrossRef]

21. Vinatoru, M. An overview of the ultrasonically assisted extraction of bioactive principles from herbs. Ultrason. Sonochem. 2001, 8, 303-313. [CrossRef]

22. Mahindrakar, K.V.; Rathod, V.K. Ultrasonic assisted aqueous extraction of catechin and gallic acid from Syzygium cumini seed kernel and evaluation of total phenolic, flavonoid contents and antioxidant activity. Chem. Eng. Process. Process. Intensif. 2020, 149, 107841. [CrossRef]

23. Caballero-Galván, A.S.; Restrepo-Serna, D.L.; Ortiz-Sánchez, M.; Cardona-Alzate, C.A. Analysis of Extraction Kinetics of Bioactive Compounds from Spent Coffee Grounds (Coffea arábica). Waste Biomass Valorization 2018, 9, 2381-2389. [CrossRef]

24. Prasad, K.N.; Yang, E.; Yi, C.; Zhao, M.; Jiang, Y. Effects of high pressure extraction on the extraction yield, total phenolic content and antioxidant activity of longan fruit pericarp. Innov. Food Sci. Emerg. Technol. 2009, 10, 155-159. [CrossRef]

25. Akhmazillah, M.F.N.; Farid, M.M.; Silva, F.V.M. High pressure processing (HPP) of honey for the improvement of nutritional value. Innov. Food Sci. Emerg. Technol. 2013, 20, 59-63. [CrossRef]

26. Okur, İ.; Baltacıoğlu, C.; Ağçam, E.; Baltacıŏ̆lu, H.; Alpas, H. Evaluation of the Effect of Different Extraction Techniques on Sour Cherry Pomace Phenolic Content and Antioxidant Activity and Determination of Phenolic Compounds by FTIR and HPLC. Waste Biomass Valorization 2019. [CrossRef]

27. Acevedo, F.; Rubilar, M.; Scheuermann, E.; Cancino, B.; Uquiche, E.; Garcés, M.; Inostroza, K.; Shene, C. Spent coffee grounds as a renewable source of bioactive compounds. J. Biobased Mater. Bioenergy 2013, 7, 420-428. [CrossRef]

28. Moreira, S.A.; Pintado, M.; Saraiva, J.A. High Hydrostatic Pressure-Assisted Extraction: A Review on its Effects on Bioactive Profile and Biological Activities of Extracts; Elsevier Inc.: Amsterdam, The Netherlands, 2020; ISBN 9780128164051. 
29. Briones-Labarca, V.; Plaza-Morales, M.; Giovagnoli-Vicuña, C.; Jamett, F. High hydrostatic pressure and ultrasound extractions of antioxidant compounds, sulforaphane and fatty acids from Chilean papaya (Vasconcellea pubescens) seeds: Effects of extraction conditions and methods. LWT Food Sci. Technol. 2015, 60, 525-534. [CrossRef]

30. Samaram, S.; Mirhosseini, H.; Tan, C.P.; Ghazali, H.M.; Bordbar, S.; Serjouie, A. Optimisation of ultrasound-assisted extraction of oil from papaya seed by response surface methodology: Oil recovery, radical scavenging antioxidant activity, and oxidation stability. Food Chem. 2015, 172, 7-17. [CrossRef]

31. Belguidoum, K.; Amira-Guebailia, H.; Boulmokh, Y.; Houache, O. HPLC coupled to UV-vis detection for quantitative determination of phenolic compounds and caffeine in different brands of coffee in the Algerian market. J. Taiwan Instig. Chem. Eng. 2014, 45, 1314-1320. [CrossRef]

32. Mussatto, S.I.; Ballesteros, L.F.; Martins, S.; Teixeira, J.A. Extraction of antioxidant phenolic compounds from spent coffee grounds. Sep. Purif. Technol. 2011, 83, 173-179. [CrossRef]

33. Xu, H.; Wang, W.; Liu, X.; Yuan, F.; Gao, Y. Antioxidative phenolics obtained from spent coffee grounds (Coffea arabica L.) by subcritical water extraction. Ind. Crop. Prod. 2015, 76, 946-954. [CrossRef]

34. Grassino, A.N.; Brnčić, M.; Vikić-Topić, D.; Roca, S.; Dent, M.; Brnčić, S.R. Ultrasound assisted extraction and characterization of pectin from tomato waste. Food Chem. 2016, 198, 93-100. [CrossRef] [PubMed]

35. Kante, K.; Nieto-Delgado, C.; Rangel-Mendez, J.R.; Bandosz, T.J. Spent coffee-based activated carbon: Specific surface features and their importance for $\mathrm{H} 2 \mathrm{~S}$ separation process. J. Hazard. Mater. 2012, 201-202, 141-147. [CrossRef] [PubMed]

36. Wang, N.; Lim, L.T. Fourier transform infrared and physicochemical analyses of roasted coffee. J. Agric. Food Chem. 2012, 60, 5446-5453. [CrossRef] [PubMed]

37. Pujol, D.; Liu, C.; Gominho, J.; Olivella, M.À.; Fiol, N.; Villaescusa, I.; Pereira, H. The chemical composition of exhausted coffee waste. Ind. Crop. Prod. 2013, 50, 423-429. [CrossRef]

38. Craig, A.P.; Franca, A.S.; Oliveira, L.S. Discrimination between defective and non-defective roasted coffees by diffuse reflectance infrared Fourier transform spectroscopy. LWT Food Sci. Technol. 2012, 47, 505-511. [CrossRef]

39. Clifford, M.N.; Kirkpatrick, J.; Kuhnert, N.; Roozendaal, H.; Salgado, P.R. LC-MSn analysis of the cis isomers of chlorogenic acids. Food Chem. 2008, 106, 379-385. [CrossRef]

40. Haussard, M.; Gaballah, I.; Kanari, N.; De Donato, P.; Barrès, O.; Villieras, F. Separation of hydrocarbons and lipid from water using treated bark. Water Res. 2003, 37, 362-374. [CrossRef]

41. Wen, L.; Zhang, Z.; Rai, D.; Sun, D.W.; Tiwari, B.K. Ultrasound-assisted extraction (UAE) of bioactive compounds from coffee silverskin: Impact on phenolic content, antioxidant activity, and morphological characteristics. J. Food Process. Eng. 2019, $42,1-11$. [CrossRef]

42. Xie, P.J.; Huang, L.X.; Zhang, C.H.; You, F.; Zhang, Y.L. Reduced pressure extraction of oleuropein from olive leaves (Olea europaea L.) with ultrasound assistance. Food Bioprod. Process. 2015, 93, 29-38. [CrossRef]

43. Gajic, I.S.; Savic, I.; Boskov, I.; Žerajić, S.; Markovic, I.; Gajic, D. Optimization of ultrasound-assisted extraction of phenolic compounds from black locust (Robiniae pseudoacaciae) flowers and comparison with conventional methods. Antioxidants 2019, 8, 248. [CrossRef] [PubMed]

44. Zhang, Z.-S.; Wang, L.-J.; Li, D.; Jiao, S.-S.; Chen, X.D.; Mao, Z.-H. Ultrasound-assisted extraction of oil from flaxseed. Sep. Purif. Technol. 2008, 62, 192-198. [CrossRef]

45. Altemimi, A.; Watson, D.G.; Choudhary, R.; Dasari, M.R.; Lightfoot, D.A. Ultrasound assisted extraction of phenolic compounds from peaches and pumpkins. PLoS ONE 2016, 11, 1-20. [CrossRef] [PubMed]

46. Benzie, I.F.F.; Strain, J. The Ferric Reducing Ability of Plasma (FRAP) as a Measure of "Antioxidant Power": The FRAP Assay. Anal. Biochem. 1996, 239, 70-76. [CrossRef] [PubMed]

47. Kuşçu, A.; Bulantekin, Ö. The effects of production methods and storage on the chemical constituents of apple pekmez. J. Food Sci. Technol. 2016, 53, 3083-3092. [CrossRef] 